\title{
Characterisation and Modelling of Drying Kinetics of Thin Ash and Oak Wood Lamellas Dried with Infrared Radiation and Hot Air
}

\section{Karakterizacija i modeliranje kinetike sušenja tankih lamela drva jasena i hrasta infracrvenim zračenjem i vrućim zrakom}

Original scientific paper • Izvorni znanstveni rad Received-prispjelo: 20. 10. 2019. Accepted-prihvaćeno: 28. 4. 2020. UDK: $630 * 847.2 ; 630 * 847.3 ; 630 * 847.7$ https://doi.org/10.5552/drvind.2020.1965
(C) 2020 by the author(s). Licensee Faculty of Forestry, University of Zagreb. This article is an open access article distributed under the terms and conditions of the Creative Commons Attribution (CC BY 4.0) license.

\begin{abstract}
Infrared and hot air drying characteristics of thin ash (Fraxinus excelsior L.) and oak (Quercus robur L.) wood lamellas were experimentally determined using an infrared and hot air laboratory device. Drying curves of $2 \mathrm{~mm}$ thick lamellas were established in the temperature range between $60{ }^{\circ} \mathrm{C}$ and $90{ }^{\circ} \mathrm{C}$, and fitted by Fick's diffusion model. Drying efficiency, drying rate and effective diffusivity have been estimated and compared between the used drying techniques. Moisture ratio exponentially decayed with duration of the process at all used temperatures. Effective diffusivity was greater in ash than oak wood, and it was not significantly influenced by the drying technique. The increased bound water diffusivity with increased drying temperature that caused shortening of the drying process was confirmed in both wood species. Similar activation energy was determined with both wood species, lower when the IR drying technique was used.
\end{abstract}

Key words: wood drying kinetics; hot air drying; infrared drying; moisture diffusion

SAŽETAK・Obilježja infracrvenog sušenja i sušenja vrućim zrakom tankih lamela drva jasena (Fraxinus excelsior L.) i drva hrasta (Quercus robur L.) utvrđene su eksperimentalno uz pomoć laboratorijskih uređaja za infracrveno sušenje i sušenje vrućim zrakom. Krivulje sušenja lamela debljine 2 mm utvrđene su u rasponu temperatura između 60 i $90{ }^{\circ} \mathrm{C}$ te su prilagođene Fickovu difuzijskome modelu. Učinkovitost i brzina sušenja te efektivna difuznost procijenjene su i uspoređene unutar primijenjenih tehnika sušenja. Omjer sadržaja vode eksponencijalno se smanjuje s trajanjem procesa pri svim temperaturama primijenjenima u eksperimentu. Efektivna je difuznost drva jasena bila veća nego drva hrasta, a tehnike sušenja nisu znatnije utjecale na nju. Za obje vrste drva potvrđena je veća difuznost vezane vode s povećanjem temperature sušenja, što je uzrokovalo skraćenje procesa sušenja. Slična je energija aktivacije utvrđena za obje vrste drva, a niža je zabilježena pri IC tehnikama sušenja.

Ključne riječi: kinetika sušenja drva; sušenje vrućim zrakom; infracrveno sušenje; difuzija vlage

\footnotetext{
${ }^{1}$ Author is associated professor at University of Ljubljana, Biotechnical Faculty, Department of Wood Science and Technology, Ljubljana, Republic of Slovenia.

2 Authors are assistant professor, PhD student and professor at University of Zagreb, Faculty of Forestry, Department of Wood Technology, Zagreb, Republic of Croatia.
} 


\section{INTRODUCTION}

\section{UVOD}

Wood is industrially most often dried on the convective heat transport phenomenon, which is energy intensive and relatively slow process, as it relies on heat conduction from the circumference towards to the interior of the board (Keey et al., 2000). For the most part of the process, moisture from wood is removed by diffusion, where the opposite moisture gradient, comparing to temperature gradient, is present for the mass transfer to the wood surface.

In order to improve the heat transfer to wood, other ways of heating the material have been explored for some time. Efficient energy transfer throughout the volume, even at greater thicknesses, was confirmed for example by dielectric radio-frequency heating (Torgovnikov, 1993) and also by microwaves (Perre and Turner, 1999; Turner and Farguson, 1995). The use of infrared radiation has proven to be an even simpler way of heating wood, however with some limitations. The latter heating techniquet was found to be limited in penetration depth (Dupleix et al., 2012b; Zavarin et al., 1990) and dependent on surface characteristics of wood (De Santo, 2007) and wood moisture content - it is more efficient when wood holds free water (Kollmann and Cote, 1968).

The laboratory and pilot studies confirmed that infrared heating is a promising alternative to soaking of wood in hot water prior to veneer peeling (Dupleix et al., 2012a), and the green wood surface can be heated up to the depth of several millimetres. It has been also demonstrated that even living trees are heated via IR radiation (Potter and Andressen, 2010). Related to wood drying, studies report on evolution of specific temperature and moisture profiles, when wood is exposed to infrared radiation (Cserta et al., 2012). The latter study specifically reports on the stagnation of lower temperature in the core of drying boards due to wood drying by osmotic effect. The evaporation of the internal moisture in this case was brought by a partial
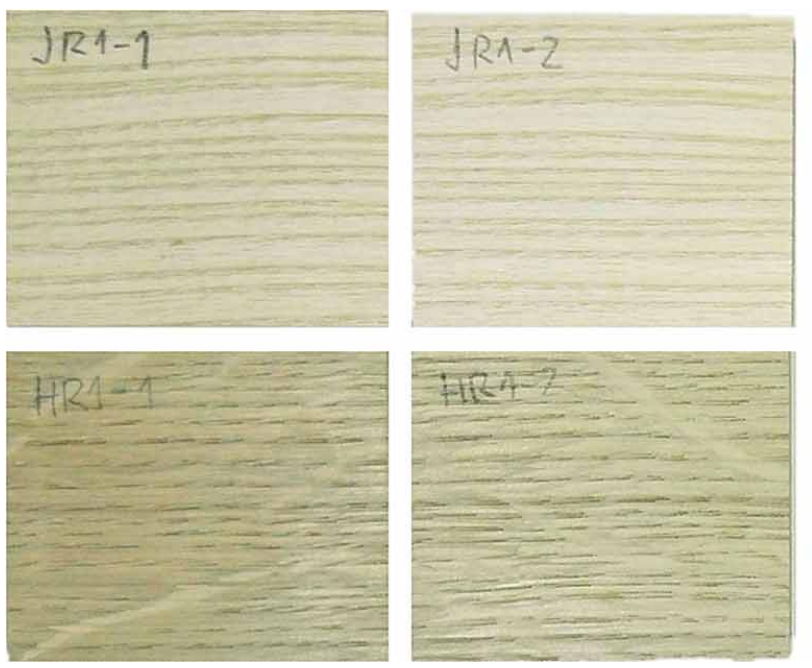

vacuum, as a result of local disappearance of liquid water. The same research group performed successfully the pilot drying process of Norway spruce exposed to IR irradiation (Cserta et al., 2011). The movement of moisture, presented as dilute aqueous solution, was described in this case as semipermeable membrane process. The intensification of sawn wood drying using IR radiation is also reported for hardwood species, but only at moisture content (MC) above fibre saturation point (Pinchewska and Kompanets, 2013). The transport of bound water by IR radiation, for example, has been studied in the drying of wood chips, where expectedly greater diffusivity was determined at the higher temperature used (Sridhar and Madhu, 2015).

This paper analyses the drying kinetics of predried thin wood lamellae, dried in normal temperature range $\left(\leq 90^{\circ} \mathrm{C}\right)$ to low $\mathrm{MC}$ by applying classical hot air convective drying and infrared-heating-drying principle. We hypothesize that the heat transfer to the wood structure is more efficient at IR drying, which might improve the bound water mass transfer at equal boundary conditions.

\section{MATERIAL AND METHODS 2. MATERIJAL I METODE}

\subsection{Sampling}

\subsection{Uzorkovanje}

Predried $\left(M C_{\mathrm{i}}=12 \%\right)$ radially oriented lamellae $(n$ $=10$ ) of ash (Fraxinus excelsior L.) and oak wood (Quercus robur L.) $5 \mathrm{~mm}$ thick, were obtained from local wood flooring manufacturer by random selection from the production process. The density of ash wood was 620 $\mathrm{kg} / \mathrm{m}^{3}$ (coef. of variation $C V=3.6 \%$ ) and for oak wood it was $605 \mathrm{~kg} / \mathrm{m}^{3}(C V=1.2 \%)$. The lamellae were then conditioned in normal climate $\left(T=20{ }^{\circ} \mathrm{C}, R H=65 \%\right)$ for 2 weeks, and afterwards planed to the thickness of 2 $\mathrm{mm}$. The thickness of the lamellae was reduced in order to have as short a drying process as possible with minimal lateral transport of moisture through the edges of the
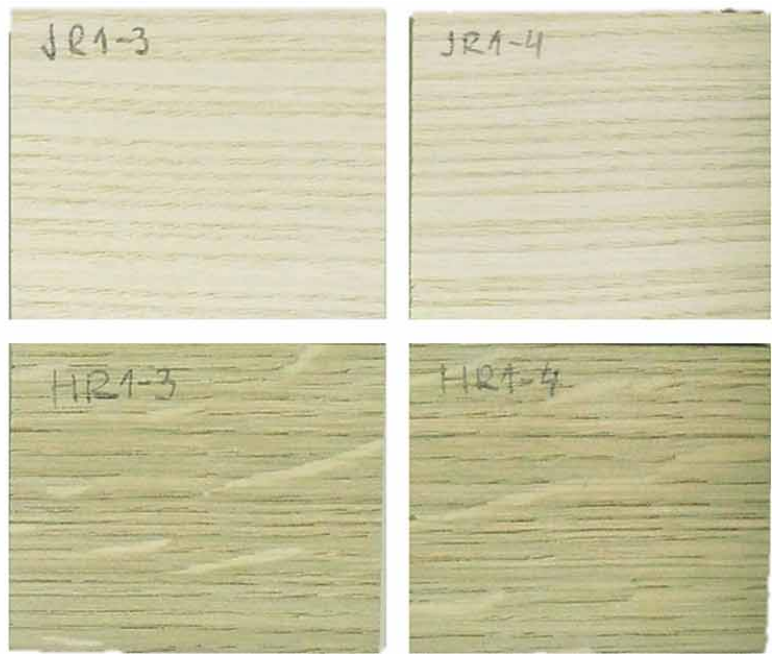

Figure 1 Parallel specimens of ash (top) and oak (bottom) for drying at temperatures of $60{ }^{\circ} \mathrm{C}(1-1), 70{ }^{\circ} \mathrm{C}(1-2), 80{ }^{\circ} \mathrm{C}(1-3)$ and $90{ }^{\circ} \mathrm{C}(1-4)$

Slika 1. Istovjetni uzorci jasena (gore) i hrasta (dolje) za sušenje pri temperaturama $60{ }^{\circ} \mathrm{C}(1-1), 70{ }^{\circ} \mathrm{C}(1-2), 80{ }^{\circ} \mathrm{C}(1-3)$ i 90 ${ }^{\circ} \mathrm{C}(1-4)$ 

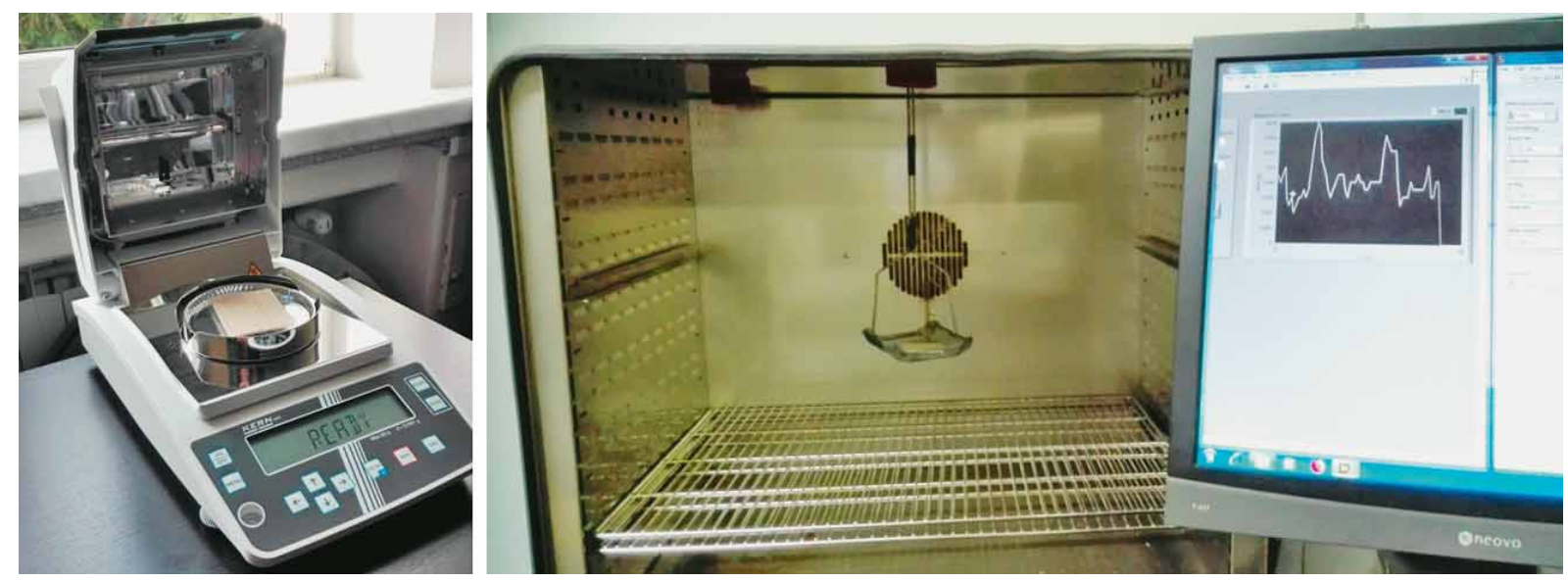

Figure 2 IR drying (left) and hot air drying experimental set-up (right)

Slika 2. IC sušenje (lijevo) i eksperimentalna komora za sušenje vrućim zrakom (desno)

test specimens. Finally, the lamellae were cut into 4 parallel test specimens of nominal dimensions 60 by 50 by 2 $\mathrm{mm}$ (length $\times$ width $\times$ thickness) (Figure 1).

\subsection{Experimental set-up and procedure}

2.2. Postavljanje eksperimenta i procedure

\subsubsection{Drying with infrared radiation}

\subsubsection{Sušenje infracrvenim zračenjem}

Infrared (IR) drying was performed in a laboratory IR-thermogravimetric moisture analyser Kern DBS 60-3. The dimensions of the dryer are typical 0.15 by 0.15 by $0.1 \mathrm{~m}$ with the above positioned electric IR heater and parabolic mirror. The test specimens were laid on a thin profiled metal mesh and on a weighing stand so that the nearest hot surfaces from the wood was only $20-30 \mathrm{~mm}$. The IR heater (halogen glass heater, $400 \mathrm{~W}, \lambda=1.5$ to $8 \mu \mathrm{m})$ maintained the constant temperature during each drying trial $\left(T_{1}=60{ }^{\circ} \mathrm{C}, T_{2}=\right.$ $70{ }^{\circ} \mathrm{C}, T_{3}=80{ }^{\circ} \mathrm{C}, T_{4}=90{ }^{\circ} \mathrm{C} ; \Delta T= \pm 0.5^{\circ} \mathrm{C}$, PIDcontrol), and the mass ( $\Delta m= \pm 0.001 \mathrm{~g})$ of the specimen was continuously captured at 1-minute intervals by NI LabView software (Figure 2).

\subsubsection{Hot air drying}

\subsubsection{Sušenje vrućim zrakom}

Hot air drying was carried out in a laboratory dryer (Kambič SP-210) with typical dimensions of 0.6 by 0.7 by $0.6 \mathrm{~m}$. The specimen carrier was placed in the middle of the chamber, and it was hung on a precise laboratory balance (Tehtnica Exacta $300 \mathrm{~EB}$ ) placed on the dryer outside. With the axial fan mounted on the back of the dryer, we maintained constant air movement $(v=1 \mathrm{~m} / \mathrm{s})$ at 4 individual drying temperatures: $T_{1}$ $=60{ }^{\circ} \mathrm{C}, T_{2}=70^{\circ} \mathrm{C}, T_{3}=80^{\circ} \mathrm{C}, T_{4}=90^{\circ} \mathrm{C}$. The mass $(\Delta m= \pm 0.001 \mathrm{~g})$ of the specimens was continuously captured at 1-minute intervals by NI LabView software (Figure 2). We ended the process with both drying techniques, i.e. IR and hot air, when the change in mass between two successive measurements was less than $0.1 \%$ of the initial mass of the specimen.

\subsection{Analysing of drying kinetics}

2.3. Analiza kinetike sušenja

The determined weight of test specimens at the beginning $\left(m_{\mathrm{i}}\right)$, during $\left(m_{\mathrm{t}}\right)$ and at the end of the drying process $\left(m_{\mathrm{e}}\right)$, when equilibrium was reached, was used to determine the dimensions less mass change, i.e. moisture ratio ( $M R$, Eq. 1).

$$
M R=\frac{m_{t}-m_{e}}{m_{i}-m_{e}}
$$

The theoretical Fick's model of mass transfer was used afterwards to analyse the kinetics of both IR and hot air drying. The model assumes that diffusivity is the sole physical mechanism responsible for the transfer of water to the wood surface. Relation between the moisture ratio and the effective diffusion coefficient was given by Crank (Crank, 1976) and this could be used for slab geometry by making an assumption that the initial moisture is uniformly distributed in the specimen. This relation was reduced to Eq. 2 assuming that the wood specimen is homogeneous, mass transfer through the wood is controlled by bound water and water vapour diffusion and effect of shrinkage is negligible.

$$
M R=\frac{8}{\pi^{2}} \exp \left[\frac{-\pi^{2} \cdot D_{\text {eff }} \cdot t}{4 \cdot L^{2}}\right]=\frac{8}{\pi^{2}} \exp \left[\frac{-\cdot t}{\tau}\right]
$$

Where $L$ is the half thickness of the wood specimen (m), $D_{\text {eff }}$ is the effective diffusion coefficient in $\mathrm{m}^{2} / \mathrm{s}$ and $t$ is the drying time in seconds. By plotting $l n$ $(M R)$ versus drying time, $D_{\text {eff }}$ was determined from the slope $(k)$ of the line, which is expected to increase with the increasing of the drying temperature. The reciprocal value of the slope $k$ is defined as well the time constant $\tau$. It is a characteristic time of the response of the first order system (FOS; Eq. 2) and equals the time when $2 / 3$ of the total response of the system is realized. According to the $1^{\text {st }}$ order system theory, $99.9 \%$ of the response, which equals the total drying time, is achieved at 5 times the characteristic time $\tau$ (Bučar, 2007).

Finally, the activation energy was estimated using Arrhenius equation (Eq. 3). In this respect, we used plot of $\ln \left(D_{\text {eff }}\right)$ versus reciprocal of absolute drying temperature $(1 / T)$ for both tested drying techniques. From the slope of the line, activation energy $E_{\mathrm{a}}(\mathrm{kJ} /$ $\mathrm{mol})$ was calculated, and from the intercept, pre-exponential factor $\left(D_{0}\right)$ was calculated (gas constant $R=$ $\left.8.314 \mathrm{~J} \cdot \mathrm{mol}^{-1} \cdot \mathrm{K}^{-1}\right)$. 


$$
D_{\text {eff }}=D_{0} \exp \left[\frac{-E_{a}}{R \cdot T}\right]
$$

\subsection{Determination of IR transmittance and IR absorbance}

2.4. Određivanje IC transmisije i IC apsorbancije

The penetration depth of IR radiation into the wood structure was checked using a FTIR spectroscope (Perkin Elmer Spectrum One). For this purpose, we made microtome slices in the radial-longitudinal plane of the wood on the sliding microtome (Leica SM2010R) of the two species studied. Transmission FTIR spectra were recorded on microtomic slices 10 to 100 microns thick $(\Delta \mathrm{L}=10 \mu \mathrm{m})$. We transformed transmission spectra into absorbance spectra and calculated mean IR transmittance / IR absorbance in the range from 4000 to $400 \mathrm{~cm}^{-1}$ (2.5 to $\left.25 \mu \mathrm{m}\right)$.

\subsection{Determination of IR-emissivity}

2.5. Određivanje IC emisivnosti

A polyvinyl chloride material (3M) with known emissivity in the spectral range $7.5-13 \mu \mathrm{m}$ (LWIR) was applied to the surface of all specimens. Thermograms were recorded with FLIR I60 thermographic camera at $50{ }^{\circ} \mathrm{C}$, and emissivity of wood in LWIR spectral range was determined with FLIR software. The measurement parameters were as follows: air temperature $21^{\circ} \mathrm{C}$, air relative humidity $52 \%$, reflected apparent temperature $20.9^{\circ} \mathrm{C}$, distance of objects surface from the lens was $120 \mathrm{~mm}$, angle of measurement in relation to the object normal was $15^{\circ}$, and airflow and dotted reflections

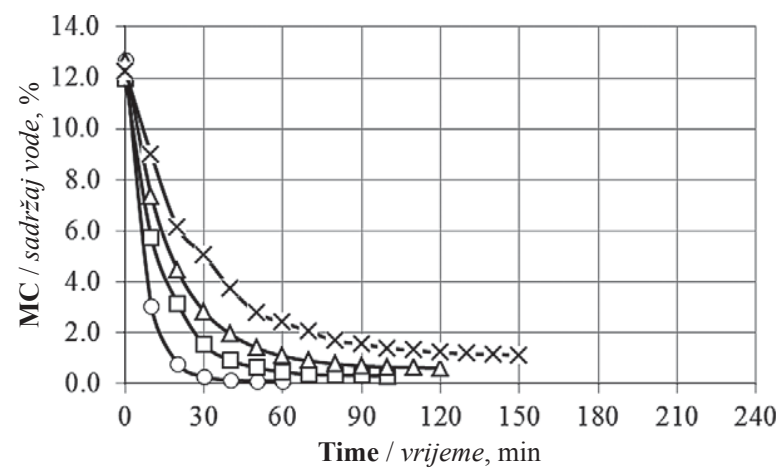

were inhibited. Eighteen measurements were conducted for each wood species.

\section{RESULTS AND DISCUSSION 3. REZULTATI I RASPRAVA}

\subsection{Drying kinetics}

3.1. Kinetika sušenja

Fick's law of diffusion described well drying kinetics of ash and oak with both used techniques in the studied temperature range $\left(0.83 \leq R^{2} \leq 0.96\right)$.

In the case of IR drying, the fastest process expectedly took place at the highest used temperature $(90$ $\left.{ }^{\circ} \mathrm{C}\right)$ and was 2 times faster in ash than in oak $\left(\tau_{\text {ash }}=7.3\right.$ $\min , \tau_{\text {oak }}=14.7 \mathrm{~min}$ ). Lowering of drying temperature significantly decreased the drying rate of both wood species tested. The slowest response was achieved with IR drying at $60{ }^{\circ} \mathrm{C}$, where the calculated (Eq. 2) characteristic drying time was $28.7 \mathrm{~min}$ for ash, and 49.0 min for oak. As different drying temperatures were used, mean final - equilibrium wood moisture content $\left(M C_{\mathrm{e}}\right)$ also varied from $1.1 \%$ at $60{ }^{\circ} \mathrm{C}$ to $0.1 \%$ at 90 ${ }^{\circ} \mathrm{C}$ (Figure 3).

The hot air drying of ash went about as fast as or slightly slower than infrared drying of this wood species. The lowest characteristic time was determined for drying at $90{ }^{\circ} \mathrm{C}\left(\tau_{90}=8.6 \mathrm{~min}\right)$, lower for drying at 80 ${ }^{\circ} \mathrm{C}\left(\tau_{80}=12.4 \mathrm{~min}\right)$ and $70{ }^{\circ} \mathrm{C}\left(\tau_{70}=23.5 \mathrm{~min}\right)$, and the lowest for drying at $60^{\circ} \mathrm{C}\left(\tau_{60}=32.1 \mathrm{~min}\right)$ (Figure 4). Hot air drying of oak was even slightly faster $(\Delta \tau=$

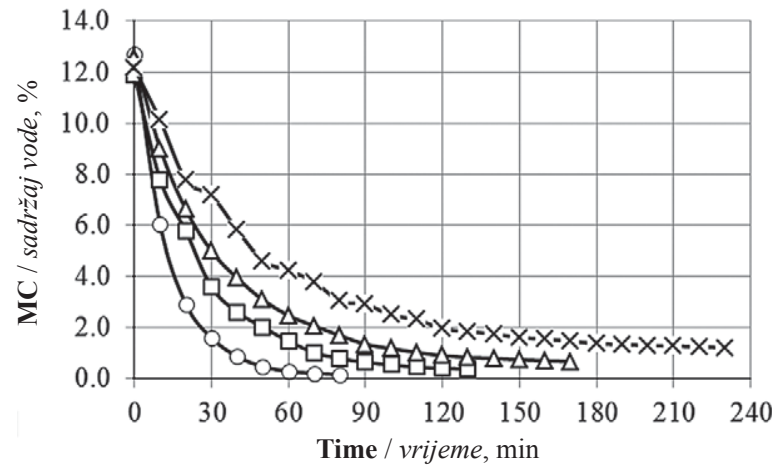

Figure 3 Kinetics of infrared drying of ash (left) and oak wood (right) at temperature between $60{ }^{\circ} \mathrm{C}$ and $90{ }^{\circ} \mathrm{C}\left(\times 60^{\circ} \mathrm{C}, \Delta\right.$ $70{ }^{\circ} \mathrm{C}, \square 80^{\circ} \mathrm{C}, \circ 90^{\circ} \mathrm{C}$ ).

Slika 3. Kinetika infracrvenog sušenja jasena (lijevo) i hrasta (desno) pri temperaturama između 60 i $90{ }^{\circ} \mathrm{C}\left(\times 60^{\circ} \mathrm{C}, \Delta 70\right.$ $\left.{ }^{\circ} \mathrm{C}, \square 80{ }^{\circ} \mathrm{C}, \circ 90^{\circ} \mathrm{C}\right)$.
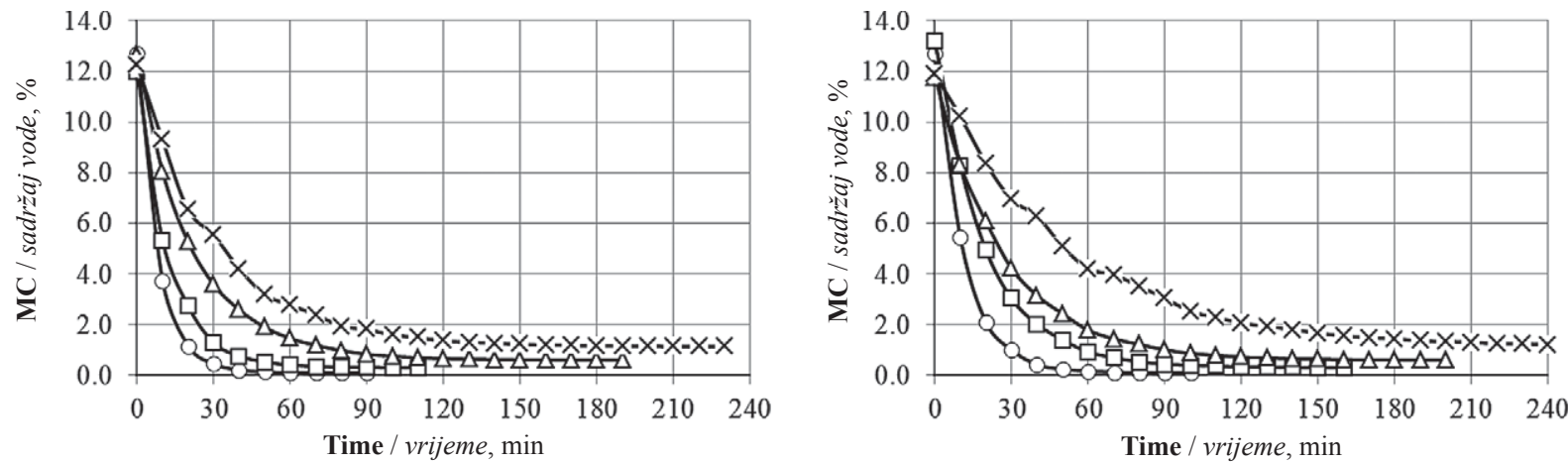

Figure 4 Kinetics of hot air drying of ash (left) and oak wood (right) at temperature between $60{ }^{\circ} \mathrm{C}$ and $90{ }^{\circ} \mathrm{C}\left(\times 60^{\circ} \mathrm{C}, \Delta 70\right.$ ${ }^{\circ} \mathrm{C}, \square 80{ }^{\circ} \mathrm{C}, \circ 90^{\circ} \mathrm{C}$ )

Slika 4. Kinetika sušenja vrućim zrakom jasena (lijevo) i hrasta (desno) pri temperaturama između 60 i $90{ }^{\circ} \mathrm{C}\left(\times 60^{\circ} \mathrm{C}, \Delta 70\right.$ $\left.{ }^{\circ} \mathrm{C}, \square 80^{\circ} \mathrm{C}, \circ 90^{\circ} \mathrm{C}\right)$ 
Table 1 Effective diffusion coefficient $\left(D_{\text {eff }}\right)$ as a function of temperature at infrared and hot air drying of ash and oak wood ( $C V$ - coef. of variation)

Tablica 1. Koeficijent efektivne difuznosti $\left(D_{\text {eff }}\right)$ kao funkcija temperature pri infracrvenom sušenju $i$ sušenju vrućim zrakom drva jasena i hrasta ( $C V$ - koef. varijacije)

\begin{tabular}{|c|c|c|c|c|c|c|c|c|}
\hline \multirow{4}{*}{$\begin{array}{l}T \\
{ }^{\circ} \mathrm{C}\end{array}$} & \multicolumn{4}{|c|}{ Ash / Jasen } & \multicolumn{4}{|c|}{ Oak / Hrast } \\
\hline & \multicolumn{2}{|c|}{ Infrared /Infracrveno } & \multicolumn{2}{|c|}{ Hot air / Vrući zrak } & \multicolumn{2}{|c|}{ Infrared / Infracrveno } & \multicolumn{2}{|c|}{ Hot air/ Vrući zrak } \\
\hline & $D_{\text {eff }}\left(\cdot 10^{-9}\right)$ & $C V$ & $D_{\text {eff }}\left(\cdot 10^{-9}\right)$ & $\mathrm{CV}$ & $D_{\text {eff }}\left(\cdot 10^{-9}\right)$ & $C V$ & $D_{\text {eff }}\left(\cdot 10^{-9}\right)$ & $C V$ \\
\hline & $\mathrm{m}^{2} / \mathrm{s}$ & $\%$ & $\mathrm{~m}^{2} / \mathrm{s}$ & $\%$ & $\mathrm{~m}^{2} / \mathrm{s}$ & $\%$ & $\mathrm{~m}^{2} / \mathrm{s}$ & $\%$ \\
\hline 60 & 0.29 & 6.8 & 0.27 & 8.4 & 0.17 & 3.1 & 0.17 & 13.0 \\
\hline 70 & 0.43 & 3.6 & 0.36 & 5.7 & 0.25 & 7.4 & 0.29 & 8.6 \\
\hline 80 & 0.60 & 6.1 & 0.68 & 13.5 & 0.34 & 6.3 & 0.41 & 8.2 \\
\hline 90 & 0.91 & 5.2 & 1.01 & 10.5 & 0.55 & 4.6 & 0.75 & 9.4 \\
\hline
\end{tabular}

$-12.5 \%$ ) compared to IR drying of this wood species. The minimum characteristic time was also measured for drying at the highest temperature $\left(\tau_{90}=11.3 \mathrm{~min}\right)$, lower for drying at $80{ }^{\circ} \mathrm{C}\left(\tau_{80}=20.3 \mathrm{~min}\right)$ and $70{ }^{\circ} \mathrm{C}\left(\tau_{70}\right.$ $=26.9 \mathrm{~min})$, and the lowest for drying at $60{ }^{\circ} \mathrm{C}\left(\tau_{60}=\right.$ $50.5 \mathrm{~min})$.

Small and insignificant differences in the kinetics of the drying processes in the tested drying techniques were also reflected in the calculated effective diffusion coefficients according to Eq. 2. When drying ash wood, the lowest diffusion coefficients were measured from $0.27 \cdot 10^{-9}$ to $0.29 \cdot 10^{-9} \mathrm{~m}^{2} / \mathrm{s}$ at $60^{\circ} \mathrm{C}$ and the highest from $0.91 \cdot 10^{-9}$ to $1.01 \cdot 10^{-9} \mathrm{~m}^{2} / \mathrm{s}$ at $90^{\circ} \mathrm{C}$ (Table 1 ). The diffusion coefficients measured in the drying of oak wood were significantly smaller compared to ash, despite the higher density of the latter $\left(\rho_{\text {ash }}=620 \mathrm{~kg} / \mathrm{m}^{3} ; \rho_{\text {oak }}=605\right.$ $\mathrm{kg} / \mathrm{m}^{3}$ ). For drying of oak wood, a diffusion coefficient of $0.17 \cdot 10^{-9} \mathrm{~m}^{2} / \mathrm{s}$ was measured at $60^{\circ} \mathrm{C}$ for both drying techniques, and maximum values of $0.55 \cdot 10^{-9}$ to $0.75 \cdot 10^{-9} \mathrm{~m}^{2} / \mathrm{s}$ were measured at $90{ }^{\circ} \mathrm{C}$. Generally, the calculated values of the diffusion coefficients in transverse direction of these two tested wood species are comparable with literature data (Siau, 1984).

From the Arrhenius equation (Eq. 3) and Arrhenius plot (Figure 5), activation energy $\left(E_{\mathrm{a}}\right)$ was found to be between 37.8 to $46.3 \mathrm{~kJ} / \mathrm{mol}$ for ash and between 38.1 to $48.3 \mathrm{~kJ} / \mathrm{mol}$ for oak, where lower values were found at infrared drying for both tested wood species. The pre-exponential factor $\left(D_{0}\right)$ was determined as $2.47 \cdot 10^{-4} \mathrm{~m}^{2} / \mathrm{s}$ and $4.54 \cdot 10^{-3} \mathrm{~m}^{2} / \mathrm{s}$ for infrared and hot air drying of ash; the values of $1.57 \cdot 10^{-4} \mathrm{~m}^{2} / \mathrm{s}$ and $5.37 \cdot 10^{-4}$

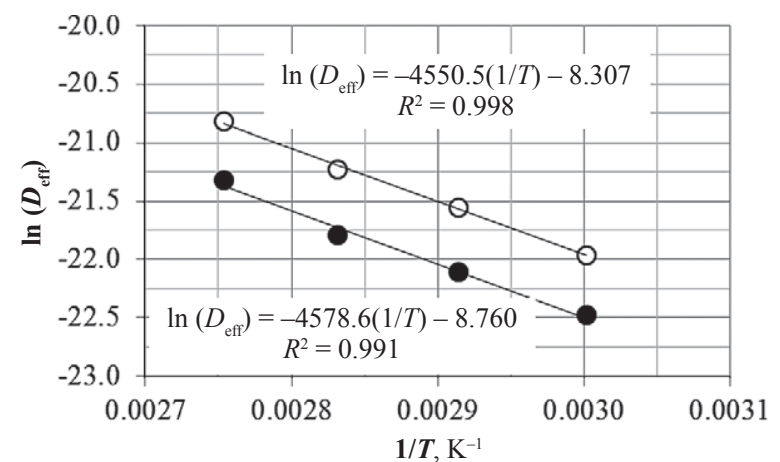

$\mathrm{m}^{2} / \mathrm{s}$ were determined for infrared and hot air drying of oak. The calculated activation energy value for bound water and water vapour diffusion in ash and oak wood is comparable to the literature data (Siau, 1984; Stamm, 1964).

Since the activation energy equals the minimum energy requirement that must be met for diffusion to occur at the studied temperature interval $\left(60\right.$ to $\left.90{ }^{\circ} \mathrm{C}\right)$, lower measured $\mathrm{E}_{\mathrm{a}}$ at infrared drying actually means better utilization of the energy input for water vapour transport in both wood species. Nevertheless, this difference in activation energy between the two processes may also be due to differences in the temperature of the subjects. For IR drying, a higher temperature in the middle of the test pieces is expected, and thus a positive correlation of temperature and moisture gradients. However, the differences between the drying techniques are small and the $\mathrm{D}_{\text {eff }}$ deviations between techniques vary at some temperatures (Table 1 ).

\subsection{Transmission and absorption of infrared} radiation in wood

3.2. Transmisija i apsorpcija infracrvenog zračenja u drvu

For both wood species, FTIR spectra were determined with a typical finger print range between 2.5 and $10 \mu \mathrm{m}$. Better transmission was determined in the higher wavelength range, in particular between 12 and 15 $\mu \mathrm{m}$, and above $20 \mu \mathrm{m}$. Expectedly, better FTIR spectra (greater difference between valleys and peaks) were determined at thinner microtome slices of both wood species (Figure 6).

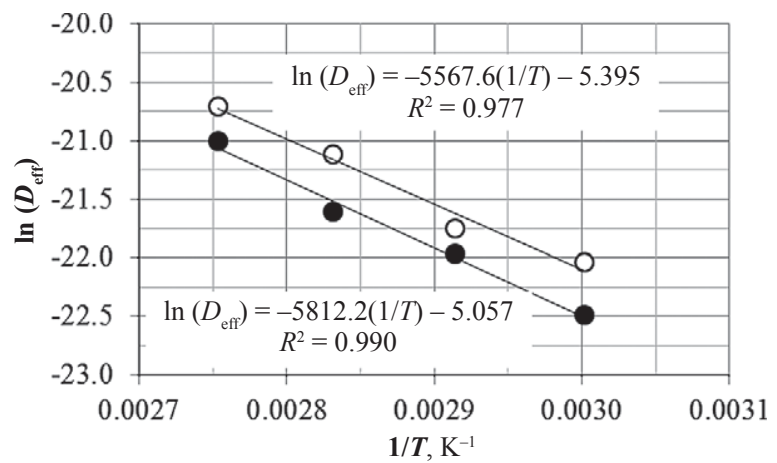

Figure 5 Relation between the reciprocal of absolute temperature and effective diffusion coefficient at infrared (left) and hot air drying (right) of wood ( $\circ$-ash, •-oak)

Slika 5. Odnos između recipročne apsolutne temperature i koeficijenta efektivne difuznosti drva pri infracrvenom sušenju (lijevo) i sušenju vrućim zrakom (desno) ( 0 - jasen, •hrast) 

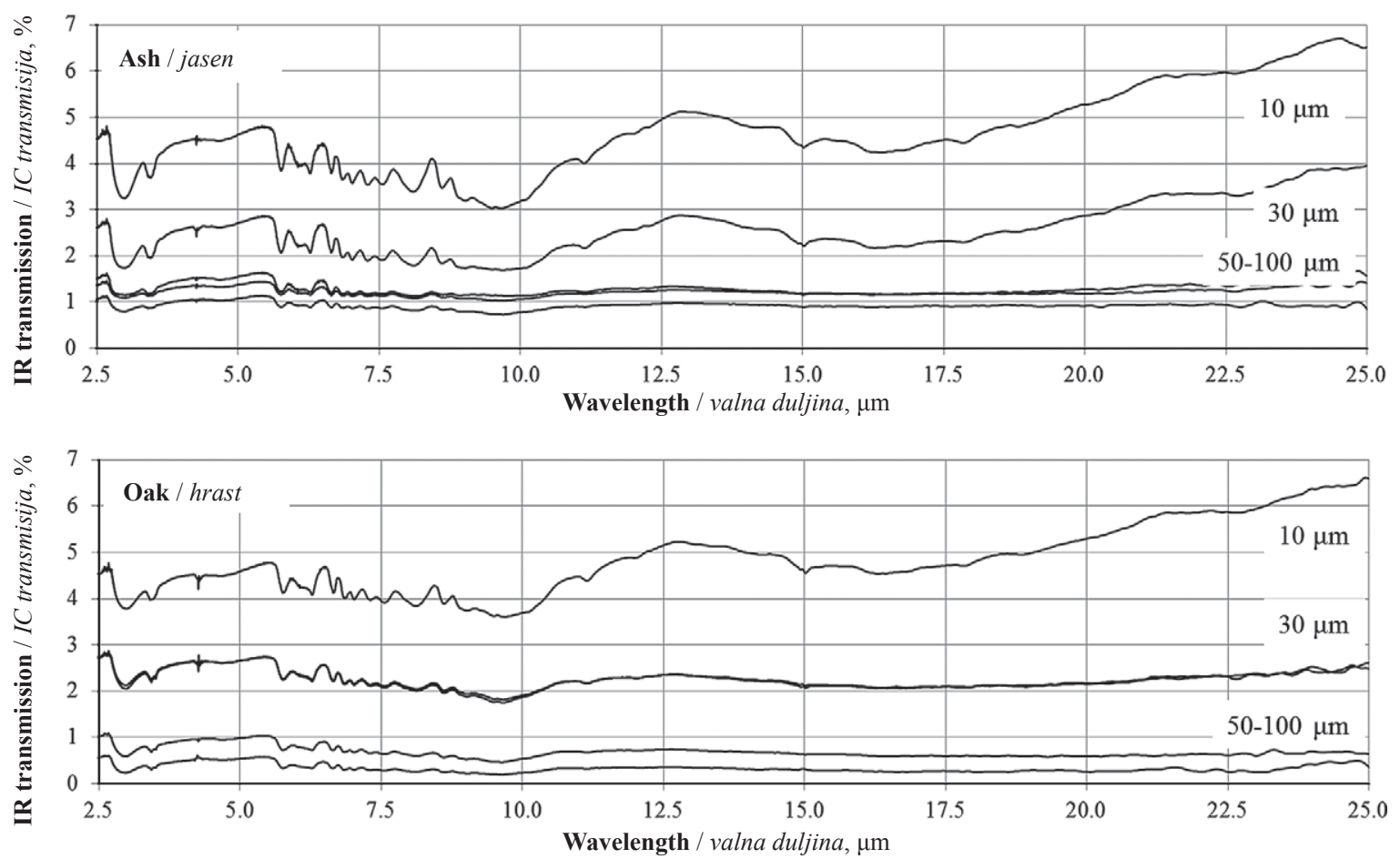

Figure 6 Transmission FTIR spectra of ash (above) and oak (below) microtome slice of different thickness (10 to $100 \mu \mathrm{m})$ Slika 6. Transmisija FTIR spektra jasena (gore) i hrasta (dolje) mikrotomskih preparata različitih debljina (od 10 do $100 \mu \mathrm{m}$ )

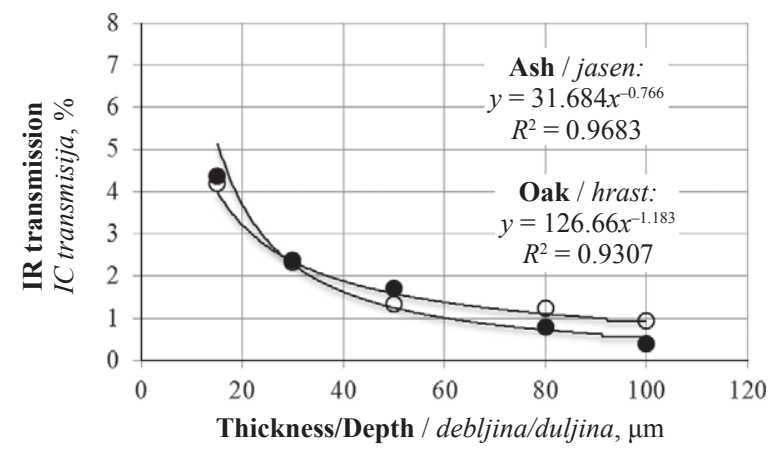

Figure 7 Relation between thickness/depth of ash (०) and oak $(\bullet)$ wood and average infrared transmission.

Figure 7. Odnos između omjera debljine/dubine drva jasena (०) i hrasta $(\bullet)$ i prosječne infracrvene transmisije

Expectedly, it turns out that the average IR transmissivity in the transmitted wavelength range (2.5 to $25 \mu \mathrm{m})$ significantly decreases with increasing microtome slice thickness of both wood species (Figure 7). The found trend, i.e. logarithmic decay of intensity of transmitted IR beam with path length, obeys the BeerLambert law. The Beer-Lambert law implies that both type (structure) and the concentration (density) of the molecules are important in the process of radiation ab- sorption (Parker, 1971). However, an insignificant difference in IR absorption between the two wood species has been confirmed.

Other studies, like ours, mention the possibility of penetrating IR radiation up to $100 \mu \mathrm{m}$ (Makoviny and Zemiar, 2004), or even to a maximum of $134 \mu \mathrm{m}$ (Zavarin et al., 1991). The latter study also reports on minor influence of wood density and fibre orientation on energy absorption and penetration depth in wood.

\subsection{Wood and emissivity of infrared light 3.3. Drvo i emisivnost infracrvenog zračenja}

No significant difference was found between IR emissivity of ash and oak samples (Table 2). Since the emissivity of a surface is its ability to absorb (and emit) energy of radiation, the more absorbent a surface is, the higher is its emissivity. It has been reported that wet wood absorbs more IR energy than dry wood and that $\varepsilon$ increases with $M C$ up to the fibre saturation point (FSP), at which point it reaches the IR emissivity of water $\left(\varepsilon_{\text {water }}=0.93\right)$ (Kollmann and Cote, 1968).

Reflectance of IR light is found to be related with the surface roughness (Jones et al., 2008). However, there is some controversy about the effect of surface roughness. Some studies highlighted that rougher the

Table 2 IR emissivity $(\varepsilon)$ of ash and oak wood samples with descriptive statistics ( $N$ - number of measurements; Mean - arithmetic mean; $S D$ - standard deviation; $95 C I$ - $95 \%$ confidence interval of the mean; Med - median; IQR - interquartile range; $C V$ - coefficient of variation)

Tablica 2. IC emisivnost $(\varepsilon)$ uzoraka drva jasena i hrasta s deskriptivnom statistikom ( $N$-broj mjerenja; Mean - aritmetička sredina; $S D$ - standardna devijacija; $95 C I$ - 95-postotni interval pouzdanosti aritmetičke sredine; Med - medijan; IQR - interkvartilni raspon; $C V$ - koeficijent varijacije)

\begin{tabular}{|l|c|c|c|c|c|c|c|c|c|}
\hline & N & Mean & SD & 95 CI & Med & IQR & Min & Max & CV \\
\hline Ash / Jasen & 18 & 0.920 & 0.011 & $0.0086-0.0171$ & 0.923 & 0.014 & 0.894 & 0.936 & 1.239 \\
\hline Oak / Hrast & 18 & 0.906 & 0.012 & $0.0093-0.0185$ & 0.909 & 0.015 & 0.876 & 0.926 & 1.365 \\
\hline
\end{tabular}


wood surface, the greater the reflection and less the IR absorption due to increased light scattering (Bennett and Porteus, 1961; De Santo, 2007). The opposite was also found (Zavarin et al., 1990; 1991). It was also reported that the effect of surface roughness on absorbance differs according to the wavelength (Tsuchikawa et al., 1996).

\section{CONCLUSIONS}

4. ZAKLJUČCI

1. Fick's law of diffusion describes well the kinetics of infrared and hot air drying of ash and oak lamellas between $60{ }^{\circ} \mathrm{C}$ and $90^{\circ} \mathrm{C}$. The calculated diffusion coefficient increased with used temperature and obeyed the Arrhenius law.

2. The diffusion of bound water and water vapour, despite greater wood density, was found to be better in ash than in oak wood, which improves the drying kinetics.

3. The use of infrared radiation did not affect significantly the drying kinetics in low wood MC range. Calculated transport coefficients of ash and oak wood, when compared to conventional hot air drying of tested species, were similar. Slightly lower activation energy for transport of bound water in wood was found at IR drying.

4. The average IR transmittance wavelength range $(2.5$ to $25 \mu \mathrm{m})$ significantly decreases with increasing wood thickness, obeying the Beer-Lambert law. IR radiation reaches ash- and oak wood depth of approx. $100 \mu \mathrm{m}$.

\section{Acknowledgements - Zahvala}

We wish to thank technical assistants, Hrvoje Kos for the preparation of drying specimens, and Luka Krže for the preparation of FTIR-microtome samples of wood. Research program No. P4-0015 was co-financed by the Slovenian Research Agency of the Republic of Slovenia from the state budget.

\section{REFERENCES}

\section{LITERATURA}

1. Bennett, H. E. J.; Porteus, J. O., 1961: Relation between surface roughness and specular reflection at normal incidence. Journal of Optical Society of America, 51: 123.

2. Bučar, B., 2007: Internal and external moisture transport resistance during non-stationary adsorption of moisture into wood. Zbornik gozdarstva in lesarstva, 84: 17-21.

3. Crank, J., 1976: The Mathematics of Diffusion, vol 2, Oxford University Press, Oxford.

4. Cserta, E.; Hegedus, G.; Nemeth, R., 2011: Dryng process in Norway spruce wood exposed to infrared radiation. BioResources, 6 (4): 4181-4189.

5. Cserta, E.; Hegedus, G.; Nemeth, R., 2012: Evolution of temperature and moisture profiles of wood exposed to infrared radiation. BioResources, 7 (4): 5304-5311.

6. De Santo, J. A., 2007: Overview of rough surface scattering. Light Scattering and Nanoscale Surface Roughness. Nanostructure Science and Technology, Springer, New York.

7. Dupleix, A.; Ahmedou, S. A. O.; Bleron, L.; Rossi, F.; Hughes, M., 2012a: Rational production of veneer by IR- heating of green wood during peeling. Holzforschung, 67: 53-58.

8. Dupleix, A.; De Sousa Meneses, D. M. H. R. M., 2012b: Mid infrared absorption properties of green wood. Wood Science and Technology, 47 (6): 1231-1241.

9. Jones, P. D.; Schimleck, L. R.; Daniels, R. F.; Clark, A.; Purnell, R. C., 2008: Comparison of Pinus taeda L. wholetree wood property calibration using diffuse reflectance near infrared spectra obtained using a variety of sampling options. Wood Science and Technology, 42 (5): 358-400.

10. Keey, R. B.; Langrish, T. A. G.; Walker, J. C. F., 2000: Kiln-drying of lumber. Springer, Hedelberg.

11. Kollmann, F.; Cote, W. A., 1968: Principles of Wood Science and Technology: Solid Wood, vol 1. Springer-Verlag, Berlin.

12. Makoviny, L.; Zemiar, J., 2004: Heating of wood surface layers by infrared and microwave radiation. Wood Research, 49 (4): 33-40.

13. Parker, F. S., 1971: Quantitative Analysis. In: Parker F. S. (ed.), Application of Infrared Spectroscopy in Biochemistry, Biology and Medicine. Springer, Boston, pp. 80-83.

14. Perre, P.; Turner, I. W., 1999: The use of numerical simulation as a cognitive tool for studying the microwave drying of softwood in an over-sized waveguide. Wood Science and Technology, 33: 445-464.

15. Pinchewska, O.; Kompanets, S., 2013: Hardwood drying intensification. Annals of Warsaw University of Life Sciences, 84: 32-35.

16. Potter, B. E.; Andressen, J. A., 2010: A finite-difference model of temperatures and heat flow within a tree stem. Revue Canadienne de Recherche Forestiere, 32: 548-555.

17. Siau, J. F., 1984: Transport processes in wood. SpringerVerlag, Berlin.

18. Sridhar, D.; Madhu, G. M., 2015: Drying Kinetics and Mathematical Modeling of Casuarina Equisetifolia Wood Chips at Various Temperatures. Periodica Polytechnica Chemical Engineering, 59 (4): 288-295.

19. Stamm, A. J., 1964: Wood and cellulose science. Ronald Press, New York.

20. Torgovnikov, G., 1993: Dielectric Properties of Wood and Wood-based Materials. Springer Series in Wood Science. Springer, Haidelberg.

21. Tsuchikawa, S.; Hayashi, K.; Tsutsumi, S., 1996: Nondestructive measurement of the subsurface structure of biological material having cellular structure by using nearinfrared spectroscopy. Applied Spectroscopy, 50 (9): 1117-1124.

22. Turner, I. W.; Farguson, W. J., 1995: A study of the power density distribution generated during combined microwave and convective drying of softwood. Drying Technology, 13: 1411-1430.

23. Zavarin, E.; Cool, L. G.; Jones, S. G., 1990: Analysis of solid wood surfaces by Diffuse Reflectance Infrared Fourier-Transform (DRIFT) spectroscopy. Journal of Chemistry Technology, 10 (4): 495-513.

24. Zavarin, E.; Cool, L. G.; Jones, S. G., 1991: Analysis of solid wood surfaces by internal-reflection fourier-transform infrared-spectroscopy. Journal of Wood Chemistry and Technology, 11 (1): 41-56.

\section{Corresponding address:}

Assoc. Prof. ALEŠ STRAŽE, PhD

University of Ljubljana

Biotechnical Faculty

Department of Wood Science and Technology

Jamnikarjeva 101, 1000 Ljubljana, SLOVENIA

e-mail: ales.straze@bf.uni-lj.si 